\title{
The Role of Nursing in Overcoming The Underutilization of Peritoneal Dialysis
}

\author{
Marcela Lara Mendes ${ }^{1}$, Camila Albuquerque ${ }^{1}$ and Daniela Ponce ${ }^{1,2 *}$ \\ ${ }^{1}$ UNESP - Botucatu School of Medicine, Brazil \\ ${ }^{2}$ USP - University of São Paulo, Brazil
}

Submission: June 27, 2018; Published: July 05, 2018

*Corresponding author: Daniela Ponce, Botucatu School of Medicine, University of São Paulo, Brazil, Email: dponce@fmb.unesp.br

Abstract

The proportion of all dialysis patients treated with peritoneal dialysis (PD) has declined significantly in last 15 years. We review the role of nursing in overcoming its underutilization. The impact of timely referral and systematic and motivational predialysis education performed by nephrolgists and nursing and the assisted PD to elderly, frail, and dependant patients, are the two key aspects of therapy evidenced to have a potential to increase PD utilization. Over the last 15 years the proportion of all dialysis patients treated with PD declined significantly in the world [1]. A general shift towards a higher age at start of dialysis treatment and increasing comorbidity cannot in whole explain the causality of this problem [2]. A special concern with reducing numbers of patients is a possible decrement in experience, expertise, and quality of PD programmes including the loss in quantity and quality of training for physicians and nurses staff. The impact of timely referral and systematic and motivational predialysis education performed by nephrolgists and nursing and the assisted PD by nursing team to elderly, frail, and dependant patients, are the two key aspects of therapy evidenced to have a potential to increase PD utilization.

\section{Mini Review}

Since predialysis education may be associated with improved survival $[3,4]$, one of the most importante additional benefits of timely referral is the opportunity for execution of aproper predialysis education. Motivating patients to start with PD takes time and persuasive talent from the dialysis team, mainly nursing, and confidence and comprehension from the patient, which are all often absent in the late-referred patients [5]. The impact of intensive or at least timely education and information on modality choice has so far only been demonstrated in retrospective studies. However with all the information about the benefits of timely predialysis referral, counselling, and education, undertaking the prospective randomised trial would seem unnecessary and unethical. Table 1 shows the observational studies that showed that with predialysis education the proportion of patients choosing PD increased and reached relatively high levels [6-10]. The patient population reaching end-stage chronic kidney disease (CKD) is growing in age, frailty, comorbidity, and dependance. This is one of the major obstacles for institution of PD as it is a form of self-delivered home based therapy. The overwhelming association of having a strong social support network and being functionally able with choosing PD emphasizes the need for assisted PD [11].
Table 1: Summary of studies on the impact of predialysis education in modality choice.

\begin{tabular}{|c|c|c|}
\hline Reference & & Modality choke (PD versus HD) \\
\hline Ahlmen et al. [6] & $(\mathrm{N}=101)$ & $\begin{array}{l}38 \% \text { chose PD versus } 24 \% \text { choosing } \\
11 \mathrm{D}\end{array}$ \\
\hline Prichard [11] & 150) & $\begin{array}{l}\text { Of } 74 \text { patknts with a free modality } \\
\text { choke } 50 \% \text { chose PD }\end{array}$ \\
\hline Little et al. [12] & $(\mathrm{N}=254)$ & $\begin{array}{l}50.9 \% \text { chose PD versus } 34.8 \% \text { of } \\
\text { controls }\end{array}$ \\
\hline Marron et al. (13] & $=626)$ & $\begin{array}{l}31 \% \text { chose PD vases } 8.3 \% \text { of } \\
\text { controls }\end{array}$ \\
\hline Ribitsdi & $(\mathrm{N}=227)$ & $\begin{array}{l}54.3 \% \text { chose PD versus } 28 \% \text { of } \\
\text { controls }\end{array}$ \\
\hline
\end{tabular}

The French experience published in 2006 has shown that patients on assisted PD were on average 74 years old, 22 years older than others, and had higher comorbidity and hospitalisation rate [12]. A Canadian survey has shown that the most prevalent conditions that act as barriers to self-care PD in elderly patients are exactly the ones that can be overcome by home assistance: decreased strength to lift PD bags, decreased dexterityorvision, anxiety, decreased cognition, and immobility [13]. In this study 
the probability of being considered eligible for PD significantly increased in the regions with home care assistance programme available. The indications for assisted PD use may be broadened from patients with physical and cognitive disabilities to patients with exhausted vascular access and haemodynamic instability during HD, thus likely extending the lives of those patients [14]. The possibility of assisted PD and family support was shown to increase PD utilisation from 23 to $39 \%$ among patients with barriers to self- care in a Canadian centre [15]. Technique failure and peritonitis rates were in general with in a cceptable limits and independente of the method of assistance (done by either nurses or family members). The possibility of having periods without assistance (e.g., the family provides assistance on weekends or helps with disconnections) enables assisted PD to become more cost-effective although elevated costs of reimbursed nursing assistance are a serious concern [16-18]. Training of staff at nursing homes for PD delivery is an additional area of a possible incremente in utilisation of PD. As conclusion PD should be regarded as a safe and efficient form of renal replacement modality; however the declining numbers of patients in PD programmes in world are a cause for concern. The proper predialysis education by nursing team is crucial fator with the largest potential to repopulate PD programmes. The possibility of offering assisted PD to elderly frail patients should be a part of a modern PD programme, since these are the patients who sequality of life on replacement therapy may benefit most from assisted modality performed by nursing team at patient's home.

\section{References}

1. AK Jain, P Blake, P Cordy, AX Garg (2012) Global trendsin rates of peritoneal dialysis. Journal of the American Society of Nephrology 23(3): 533-544.

2. C van Walraven, DG Manuel, G Knoll (2014) Survival trends in ESRD patients compared with thegeneral population in the United States. American Journal of Kidney Diseases 63(3): 491-499.

3. GM Devins, DC Mendelssohn, PE Barre, K Taub, YM Binik (2005) Predialysis psychoeducational intervention extends survival in CKD: a 20-year follow-up. American Journal of KidneyDiseases 46(6): 10881098.

4. DH Kim, M Kim, H Kim, Kim YL, Kim YS, et al. (2013) Early referral to a nephrologist improved patient survival: prospective cohort study for end-stage renal disease in Korea. PLoSONE 8(1): IDe55323.

5. N Lameire, JP Wauters, JL Gorriz Teruel, W Van Biesen, R Vanholder (2002) An up date on the referral pattern of patients with end-stage renal disease. Kidney International 61(80): 27-34.
6. J Ahlmen, L Carlsson, C Schonborg (1993) Well-informed patients with end-stage renal disease prefer peritoneal dialysis to hemodialysis. PeritonealDialysis International 13(2): S196-S198.

7. SS Prichard (1996) Treatment modality selection in 150 consecutive patients starting ESRD therapy. Peritoneal Dialysis International 16(1): 69-72.

8. J Little, A Irwin, T Marshall, H Rayner, S Smith (2001) Predicting a patient's choice of dialysis modality: experience in a United Kingdom renal department. American Journal of KidneyDiseases 37(5): 981986.

9. B Marron, JC Martınez Ocana, M Salgueira, Barril G, Lamas JM, et al. (2005) Analysisof patient flow into dialysis: role of education in choice of dialysis modality. Peritoneal Dialysis International 25(3): S56-S59.

10. Ribitsch, B Haditsch, R Otto, Schilcher G, Quehenberger F, et al. (2013) Effects of a pre-dialysis patient education program on the relative frequencies of dialysis modalities. Peritoneal Dialysis International 33(4): 367-371.

11. D Chanouzas, KP Ng, B Fallouh, J Baharani (2012) What influences patient choice of treatment modality at the predialys is stage? Nephrology Dialysis Transplantation 27(4): 1542-1547.

12. T Lobbedez, R Moldovan, M Lecame, B HuraultdeLigny, W El Haggan, et al. (2006) Assisted peritoneal dialysis. Experience in a French renal department. Peritoneal Dialysis International 26(6): 671-676.

13. MJ Oliver, RR Quinn, EP Richardson, AJ Kiss, DL Lamping, et al. (2007) Home care assistance and the utilization of peritoneal dialysis. Kidney International 71(7): 673-678.

14. MRG Franco, N Fernandes, CA Ribeiro, AR Qureshi, JC divino Filho, M daGl'oriaLima (2013) A Brazilian experience in assisted automated peritoneal dialysis: are liable and effective home care approach. Peritoneal Dialysis International 33(3): 252-258.

15. MJ Oliver, AX Garg, PG Blake, Johnson JF, Verrelli M, et al. (2010) Impact of contraindications, barriers to self-care and support on incident peritoneal dialysis utilization. Nephrology Dialysis Transplantation 25(8): 2737-2744.

16. C Castrale, D Evans, C Verger, Fabre E, Aguilera D, et al. (2010) Peritoneal dialysis in elderly patients: report from the French Peritoneal Dialysis Registry (RDPLF). Nephrology Dialysis Transplantation 25(1): 255262.

17. A Smyth, E McCann, L Redahan, B Lambert, GJ Mellotte, et al. (2012) Peritoneal dialysis in an ageing population: a 10-year experience. International Urologyand Nephrology 44(1): 283-293.

18. M Dratwa (2008) Costs of home assistance for peritoneal dialysis: results of a European survey. Kidney International 73(108): S72-S75. 
(C) This work is licensed under Creative (1) Commons Attribution 4.0 License BY DOI: 10.19080/JOJNHC.2018.08.555741

\section{Your next submission with Juniper Publishers} will reach you the below assets

- Quality Editorial service

- Swift Peer Review

- Reprints availability

- E-prints Service

- Manuscript Podcast for convenient understanding

- Global attainment for your research

- Manuscript accessibility in different formats ( Pdf, E-pub, Full Text, Audio)

- Unceasing customer service

Track the below URL for one-step submission https://juniperpublishers.com/online-submission.php 